\title{
Exemplary Leadership Style and Other Leadership Styles Associated with Exemplary Practices
}

\author{
Sulpakar Sulpakar ${ }^{1}$, Ridwan Ridwan ${ }^{2}$, Herdian Herdian ${ }^{3}$, Sudjarwo Sudjarwo ${ }^{4}$, Hasan Hariri ${ }^{5}$ \\ ${ }^{1,3,4,5}$ Education Doctor Program, FKIP. Universitas Lampung, Bandar Lampung City, 35141, Indonesia \\ ${ }^{2}$ SMP Negeri 3 Way Pengubuan, Central Lampung Regency, 34164, Indonesia \\ * Corresponding Author: sulpakar.s3@gmail.com
}

Received: June 9, 2021. Revised: December 7, 2021. Accepted: December 24, 2021. Published: January 9, 2022.

\begin{abstract}
This literature review aims to analyze three research designs, namely quantitative, mixed-method, and qualitative using exemplary leadership diction. The method used is the VoS Viewer bibliometric method to search and, in the end, the authors determine the articles reviewed. The results show that 1) quantitative research designs are confirmatory factor analysis centered on Kousez and Posner's exemplary leadership, 2) mixed methods design studies focus on the Kennedy Leadership Qualities. Kennedy's five leadership qualify cultural differences: a) making variety a preference, b) getting to knowing personalities and their variations, c) enabling valuable connection, d) liability as an essential advantage, e) mutualism as the ultimate arbiter, and 3) meanwhile, in the qualitative research design, exemplary diction is more heroic, which relies on one role model with all the sacrifices, dedication, risk, and skills to adapt the application of various leadership styles associated with exemplary diction. It is clear that to apply exemplary diction requires sharp intuition of leadership, the intelligence to mix several styles, and the courage to take risks.
\end{abstract}

Keywords-associated, exemplary leadership, leadership practice, qualitative, quantitative, mixed method.

\section{INTRODUCTION}

$\mathrm{T}$ HE attention of researchers, theorists, and social scientists in predicting the behavior patterns of a leader and follower remain an ever-challenging topic. Building on the literature on followers and leadership, it is necessary to adopt an inverted lens approach in leadership research by hypothesizing that followers should dare to assist in the development of exemplary leadership practices. However, this review literature focuses on leader behavior associated with the word exemplary.

Research with the topic of exemplary is relatively difficult to obtain, especially literature review research that summarizes the behavior of leaders who are incorporated in the word exemplary. This literature review is important because it is able to summarize, understand, and cut a long span of time to make it easier for future researchers to carry out further research with different backgrounds, cultures to add to the void of understanding research with exemplary topics.

Building a better organization needs an equilibrium between encouraging administration and following abilities because trustworthy following abilities lead to productive leadership improvement [1]. Organizations fail partly because of leadership incompetence and partly because of reckless members [2]. In connection with administration roles, a society of gallant follower performance is very important which will support the organization to progress in the globalized environment [3]. Chaleff [4] defines gallant members as people who take liability for themselves and assist administrators in organizational increase. Such a responsible way promotes members' ability to take responsibility for their own job. The essence of a powerful administration method depends on the powerful capabilities of the manager and followers.

Now's competing for global conditions requires the capacity of members as co-producers of management; members must bear liability and possession of the organization. On the other hand, researchers criticize that excessive administration center has managed to simply of the position of followers in the group [5]. An academic study by Uhl-Bien, Riggio, Lowe, and Carsten requests for shifting the eyeglass way by studying administration way as the receiver of follower role. The aforementioned method requires study to turn around early questions about administration when management methods are analyzed as a result of followers [6]. The center of this method is whereby the follower function recognizes the management role and its consequences because it is through the lens of followers that follower behavior amplifies management capability [7].

To build an organization favorably, there is a necessity to know both functions concurrently [1]. Studying gallant followership role encourages selves to carry out the model way, to see their role as a liable and reliable part of an association [8]. On the other hand, studying sufficient 
followership role is thought an oxymoron, each person desires to be a great leader, not a great member. Groups waste a lot of money in coaching superintendents to acquire great leadership abilities. In truth serving and managing mutually performs real leadership. Accordingly, in now's changing circumstances we demand to understand the function of genuine members and followers in the development of leadership abilities.

Research on the role of exemplary is still rarely done in quantitative, mixed-method, and qualitative designs, especially literature-based research. This literature review intends to investigate the different roles of exemplary in quantitative and qualitative research designs. However, leadership practices related to role models are applied in many leadership practices, especially qualitative research. This paper intends to analyze leadership practices related to exemplary role practices found in quantitative, mixed, and qualitative research.

\section{RESEARCH OBJECTIVES AND QUESTIONS}

This literature review was conducted to critically review what is the focus of research on the quantitative and qualitative design of exemplary leadership practice by analyzing the practices stored in the literature, with the research question: "What focus is researched in quantitative, mixed method, and qualitative research designs in exemplary leadership practice?" to guide this research.

\section{METHOD}

The literature review was conducted using the VOS viewer bibliometric framework. This literature review is about exemplary leadership focusing on its research design. This literature review process begins with the search engine Table 1 Result of Analysis

\begin{tabular}{|c|c|c|c|}
\hline No & Writer/s and Year & Research design & Important points \\
\hline 1 & McDonald [9] & $\begin{array}{l}\text { Literature review } \\
\text { on history notes }\end{array}$ & $\begin{array}{l}\text { The desire of a leader to release his nation and state under the rule of } \\
\text { another country and the desire to become a state that regulates and } \\
\text { manages the country as a form of self-determination. }\end{array}$ \\
\hline 3 & $\begin{array}{l}\text { Khan and Soomro } \\
{[10]}\end{array}$ & $\begin{array}{l}\text { Quantitative/93 } \\
\text { respondents }\end{array}$ & $\begin{array}{l}\text { The results reveal that 'Enable Others to Act' is the most powerful method } \\
\text { with a mean of } 4.12 \text { and an sd of } 0.700 \text {. The second is 'Challenge the } \\
\text { Process' with a mean of } 4.01 \text { and an sd of } 0.764 \text {. The third is 'Push the } \\
\text { Heart' with a mean of } 4.00 \text { and a standard deviation of } 0.771 \text {. Followed by } \\
\text { 'Inspired a Shared Vision' with a mean of } 3.97 \text { and an sd of } 0.739 \text {. The } \\
\text { lowest score was the 'Model of the Way' element with a mean of } 3.77 \text { and } \\
\text { an sd of } 0.768 \text {. }\end{array}$ \\
\hline
\end{tabular}

Harzing's Publish or Perish to search for articles with the keywords "exemplary leadership" 2017-2021.

Based on a search with a maximum number of results 50 with a limit of 2017 to 2021, 16 items and 5 clusters consisting of cluster 1 there are 4 items, namely application, evidence, exemplary model, and student; cluster 2 contains 4 items, namely behavior, impact, organization, and value; cluster 3 contains 3 items, namely exemplary leadership practice, paper, and relationship; cluster 4 contains 3 items, namely Kouzes, Posner, and transformational leadership; and cluster 5 there are 2 items, namely cognitive leadership, and example. Meanwhile, based on the year of research, exemplary leadership is connected with exemplary leadership practice, power, and evidence variables.

The criteria included in this study were 3 selected articles, one quantitative design as its representative. This is because the quantitative research design focuses on testing confirmatory factor analysis instruments belonging to Kouzes and Posner (2003) which are applied in the field of study and various research settings, such as health, business, and education. Meanwhile, qualitative designs are relatively rare and difficult to find. Two articles were selected because they cover the topics contained in other articles. The results of the study from the three selected articles are presented in the results section as follows.

\section{RESULTS}

Here the authors present study on exemplary leadership which includes the titles and journals, authors and years, research designs, and important points contained in the articles. 


\begin{tabular}{|c|c|c|c|}
\hline & & & sharing materials, and awards for the most qualified workers. \\
\hline 5 & Khan [12] & $\begin{array}{l}\text { Quantitative } \\
\text { research }\end{array}$ & $\begin{array}{l}\text { Psychological capital and psychological ownership act as predictors of } \\
\text { transactional leadership practices. The application of the right transactional } \\
\text { leadership style will provide good work performance for workers. }\end{array}$ \\
\hline 6 & Ghias, Hassan [13] & $\begin{array}{l}\text { Quantitative } \\
\text { research }\end{array}$ & $\begin{array}{l}\text { Employees who work effectively help develop leadership in their } \\
\text { organizations. Leaders should be able to identify members who perform } \\
\text { well to serve as role models because the contribution of workers like this } \\
\text { can inspire commitment and organizational growth and development. }\end{array}$ \\
\hline 7 & $\begin{array}{l}\text { Dematthews and } \\
\text { Izquierdo [14] }\end{array}$ & $\begin{array}{l}\text { Qualitative } \\
\text { research }\end{array}$ & $\begin{array}{l}\text { Principals solve problems through an equal approach between schools and } \\
\text { parents. The principal does not place himself above his parents. This } \\
\text { equality approach is able to solve the problems that schools face. }\end{array}$ \\
\hline 8 & $\begin{array}{l}\text { Eisenschmidt, } \\
\text { Kuusisto [15] }\end{array}$ & Qualitative & $\begin{array}{l}\text { This leader figure is able to work together with all elements of stakeholders } \\
\text { including teachers, students, parents, and society as a whole. The principal } \\
\text { uses his authority to improve education and develop change for the better } \\
\text { in the long term. This leader is able to do all that because he is kind, } \\
\text { righteous, caring, fair, participative. This leadership practice is close to } \\
\text { values-based leadership. }\end{array}$ \\
\hline 9 & Zaharris, Sims [16] & Qualitative study & $\begin{array}{l}\text { There is a similarity between spiritual values and exemplary leadership. } \\
\text { The millennial community needs to get this leadership as a form of } \\
\text { balancing between the needs of life, meaning, and work goals. }\end{array}$ \\
\hline 10 & $\begin{array}{l}\text { Díaz, Sánchez- } \\
\text { Vélez [17] }\end{array}$ & $\begin{array}{l}\text { Quantitative } \\
\text { research }\end{array}$ & $\begin{array}{l}\text { To produce entrepreneurs, it is important for teachers to focus on self- } \\
\text { efficacy for entrepreneurship. Exemplary leadership takes a number of } \\
\text { steps, such as helping teachers evaluate curricular and co-curricular } \\
\text { entrepreneurship improvement programs. This practice has been } \\
\text { successfully applied in Spain and Mexico. }\end{array}$ \\
\hline 11 & $\begin{array}{l}\text { Díaz, Sánchez- } \\
\text { Vélez [17] } \\
\text { ProQuest Doctoral } \\
\text { dissertation, } \\
\text { Brandman } \\
\text { University. }\end{array}$ & $\begin{array}{l}\text { Phenomenological } \\
\text { qualitative study }\end{array}$ & $\begin{array}{l}\text { Conclusion: Exemplary leaders (a) engage in dialogue to improve } \\
\text { stakeholder relations; (b) encourage easy-to-use interactive dialogue (c) } \\
\text { build support to ensure clear organizational pathways with understanding, } \\
\text { targeting, and well-designed dialogue with all stakeholders; and (d) } \\
\text { communicate and model clear expectations for managing stakeholders and } \\
\text { ensuring clarity of organizational objectives. }\end{array}$ \\
\hline 12 & $\begin{array}{l}\text { Peter and Sunday } \\
{[18] / \text { International }} \\
\text { Journal of } \\
\text { Psychology and } \\
\text { Cognitive Science }\end{array}$ & $\begin{array}{l}\text { Quantitative, an } \\
\text { exploratory } \\
\text { research design }\end{array}$ & $\begin{array}{l}\text { The findings show that the dimensions of exemplary leadership namely: } \\
\text { modeling a path, inspiring a shared vision, and process challenges all show } \\
\text { important relationships with subordinate dedication in the private } \\
\text { healthcare sector. There is a direct and important link between exemplary } \\
\text { leadership and the dedication of subordinates in the private healthcare } \\
\text { sector at Port Harcourt. Strong swallow leadership is the key to earning } \\
\text { huge sustainable profits by increasing employee dedication. }\end{array}$ \\
\hline 13 & $\begin{array}{l}\text { Maiden }[19] / \\
\text { International } \\
\text { Practice } \\
\text { Development } \\
\text { Journal }\end{array}$ & Qualitative & $\begin{array}{l}\text { This research uses Borton's Reflective Framework; this analysis uses the } \\
\text { practice of Kouzes and Posner. Conclusions and implications for practice: } \\
\text { - Structured review and use of creative approaches can enhance leadership } \\
\text { skills and are powerful tools in the expansion of transformational } \\
\text { leadership at all levels of health institutions. } \\
\text { - Leadership development is critical for all members of the health care } \\
\text { team, not just health managers, and must be nurtured across the entire } \\
\text { team. } \\
\text { - Transformational leadership and structural change in health care } \\
\text { institutions are critical to promoting a proactive and integrated care system }\end{array}$ \\
\hline 14 & $\begin{array}{l}\text { Martín Pérez } \\
{[20] / \text { Dissertation }}\end{array}$ & $\begin{array}{l}\text { Sequential } \\
\text { explanatory mixed } \\
\text { methods }\end{array}$ & $\begin{array}{l}\text { Exemplary leadership practice is to apply (a) explicitly implement } \\
\text { individual accountability for cultural inclusivity (b) discard behavior as a } \\
\text { gatekeeper of restrictions, (c) destroy the status quo, (d) have knowledge of } \\
\text { their individual behavior control, (e) build values and specific beliefs of } \\
\text { individuals and organizations, (f) providing programs for input and } \\
\text { feedback from various stakeholders, (g) promoting a shared vision and } \\
\text { values of equality with stakeholders, and (h) bilingual code-switching } \\
\text { practices to create good relationships that sincere. }\end{array}$ \\
\hline 15 & Jackson [21]/ & Qualitative & Findings: three exemplary technology administrators adopted behaviors \\
\hline
\end{tabular}


Dissertations

related to personality, vision, relationships, enlightenment, and inspiration to lead their companies.

Conclusion: combining the five components of leadership qualities, vision, relationships, wisdom, and inspiration elevates the leadership framework for understanding how the company and its members mean. The findings of this study underscore the call for technology leaders to emerge in ways that actively communicate the five components of leadership to their members.

$\begin{array}{lll}16 & \text { Hodge [22]/ } & \text { A Mixed-Methods } \\ \text { Dissertation } & \text { Case Study }\end{array}$
Findings: A literature review shows the importance of character, inspiration, relationships, vision, and wisdom as leadership skills and in building personal and organizational meaning. This investigation shows that exemplary leaders build interest in themselves, their organizations, and their followers through behaviors that demonstrate positive character, inspiration, relationships, vision, and wisdom.

Conclusion: Behaviors related to exemplary are character, inspiration, relationships, vision, and wisdom by technical implementing officials of the organization.

$17 \begin{array}{ll}\text { Dodge }[23] / & \text { An explanatory } \\ \text { mixed-method } \\ \text { design }\end{array}$

Conclusion: This research sets out and illustrates the leadership approach that principals should use to develop inclusive organizational practices by leveraging Kennedy's (2008) leadership qualities regarding cultural differences a) creating diversity, b) comprehending individuals and their differences, c) sustaining relations the rich, d) obligation as a central value, e) mutualism as the final arbitrator.

\section{V.DISCUSSION}

This literature review focuses on research designs quantitative, mixed-method and qualitative. Here's the presentation.

\section{A. Exemplary leadership in quantitative research}

Browing [24] states that leadership is an affiliation that depends on diverse components of manners that will be required to modify as the possibilities alterations. Cowie and Crawford [25] suggested that a prominent leader counts on the attributes, values, and instruments obtainable to negotiate with current requirements. Brauckmann and Pashiardis [26] recognize that leadership is a basic determinant in the triumph of any method including school. Duignan [27] acknowledges that leadership methods are leadership movements that are concentrating and likened to corporate survival. The leader negotiates with the fellows of the group and assurances that the duties of the organization are achieved.

Kouzes and Posner [28] claim that leadership is a capability and capacity that can be modified and enhanced by the intention to develop a more acceptable leader. Kouzes and Posner [29] emphasize the Leadership Practice Inventory (LPI) which focuses on behavioral determinants that supply effective leadership methods. Kouzes and Posner [30] have earlier composed the Exemplary Leadership Model which obliges as an intended design and suits the best assortment of models as it eradicates organizational tribulations. Ordinarily, it holds solutions to solve impediments that occur with specific traditions. The five components of exemplary leadership are Modeling the way, Inspiring a shared vision, Challenging the Process, Enabling others to take action, and Encouraging the heart.

\section{Modeling the way}

Victorious leaders in this appointment of leadership specified the regulations for themselves and establish dedication to their significance every single day. These leaders contribute time with their fellows frequently working beside them or requesting inquiries to encourage members to demonstrate their own significances [30]. Modeling the way is basically concerning obtaining the privilege and recognition to influence within direct individual dedication and endeavor. Individuals follow the person first, then the agenda [30].

The considerable friendly concepts of leadership are leading as a function of an example person for their fellows, passionate motivation which constitutes pushing and boosting fellows by providing worth and demand to fellows assignment, mind stimulation which comprises stimulating associates to be resourceful and fruitful, an individualized reflection which comprises a personal notice on every self's requirement for accomplishment and germination [31].

\section{Inspiring a shared vision}

Leaders who want to build something different manifest their attitude in the lead. This leader holds his leadership concept and strives for the concept of being realized. Therefore, they understand the values, expectations, and aspirations of the members. Language leaders with style and diction can be understood by their followers to equalize their views and resolve problems to achieve a common goal [30].

Mulford and Silins [32] said that the behavior of leaders who occupied the position of the principal who was able to harmonize between the values and trust of the organization was responsible for the school objectives and the next impact was that this leader could influence his non-structured performance. and student achievements. Orr and Orphanos [33] said that school work was very much. But so if the work rooted in the school personality will increase understanding and lead to schools that have PASI and measured goals. 


\section{Challenging the process}

Seeking and setting new, better-quality goals is a hallmark of this leader trait. What the leader has in mind is that he always wants to get better results from day to day through innovative activities by absorbing the aspirations of his followers. The gift of such a leader is that he or she is willing to acknowledge and encourage new thinking while acknowledging new achievements and regularities. This leader cares for his followers to manage the current situation while looking for improvement opportunities by challenging his followers to change the old situation to a new better situation [30]. For this reason, schools require principals who have intellectual stimulation which means challenging teachers to appear professional to meet the needs of the school as a whole [34].

\section{Enabling others to act}

This method is confirmed by leaders who promote collaboration and develop belief among members so that a great job can be achieved. These leaders do not grasp the capability to themselves; they struggle to get members to feel strong, capable, and dedicated [30]. When members feel taken and authorized to execute judgments, they struggle vigorously and surpass their own expectations [30].

Sammons, Gu [35] believe that the practice covers a broad field that is solid with an underlying leadership dimension that can manage school and classroom approaches and activities that have been adopted by principals and staff to improve student achievement which will later turn out to be predictive improvement of school academic achievement.

\section{Encourage the hearts}

The aforementioned manner is confirmed by leaders who understand the participation offered by other people [30]. Leaders practice presentations and routines to empower others to understand the advantages of joining a practice with excellence. In addition, the leader performs a powerful group personality that takes the organization by hard moments [30].

Particular deliberation is a portion to pay attention to and appreciate the teacher's individual emotions and requirements. Leadership nourishes the basic necessities of members, highlights actions or transfers between managers and their members, and is portrayed by control by separation and contingent rewards. Leaders also inform workers what to do to be compensated for their works [36]. A review of the literature exposes the quality of nature, inspiration, connections, vision, and understanding as leadership abilities and informing individual and organizational meaning. The investigation showed that exemplary leaders generate meaning for themselves, their institutions, and their members through acts that confirm positive attitude, inspiration, connections, insight, and understanding. Of the five variables, relationship, vision, and character are the most cited behaviors in shaping interest.

\section{B. Exemplary diction in qualitative research}

Different from quantitative research which mostly focuses on exemplary leadership [30], research on exemplary leadership in qualitative design emphasizes the struggle of a leader who places himself as an exemplary person. As a result, leaders who apply various styles tend to adapt to the conditions of their followers [14, 37].

\section{In the perspective of entrepreneurship and leadership education}

The development of entrepreneurial leadership is a superiority raised by instructional systems in various parts of the world [38]. Bagheri, Lope Pihie [39] record that learners involved in entrepreneurship learning improve intrapersonal and interpersonal competencies that assist them thoroughly after they finish their undergraduate teaching. They write that institutions and programs also serve from finding job-relevant education results and practices referred to in leadership education. Nevertheless, entrepreneurial plans are extremely reliant on cultural effect, and thoughts of the suitability of instructional practices alter according to demographics such as country of origin or gender [40]. Galloway, Kapasi [41] claim that powerful entrepreneurship indicates the choosing of a current leadership strategy that welcomes justice, and subjects the traditionally received conceptualization of entrepreneurship that puts too much weight on business making. The aforementioned dispute fits with the large expanse for entrepreneurship training with the debate that entrepreneurs or managers perform their characters based on their capacity to innovate, respond proactively, and grasp chances[42]. This practice is compatible with individuals beginning new businesses, but it also employs those working at built companies in various capacities. In fact, that entrepreneurs who want to grow an entrepreneurial corporate culture should adopt applicants who exhibit transformational leadership features [43].

Hence, it is improper to represent entrepreneurship education only as a method of overcoming unemployment among people who cannot obtain a job [44]. The results included in entrepreneurship and management teaching are much more extensive, showing the demand for well-prepared organizations tasked with assisting their learners to expand the competencies they require to manage fruitful lives. This research is based on the case that teachers liable for creating and performing curricular or co-curricular plans intended to help their learners involve in fruitful professional pathways require more knowledge than is currently possible [45]. A good method to assist accomplish this is to bridge the research gap between entrepreneurial orientation and transformational leadership (Muchiri \& McMurray, 2015), which teachers can start to do by combining leadership theory into the curriculum [46], which teachers can start to do by combining leadership theory into the curriculum [47]. or the objectives of this study, transformational leadership is compatible with Kouzes and Posner's model, which explains a leader-follower connection as one in which members levitate each other to higher levels of achievement [48]. 


\section{In the perspective of culture, assessment, and self-} efficacy

Research on subjective well-being compared data used to estimate levels of considerable satisfaction, happiness, and positive and negative sensations between Mexican and Spanish undergraduate students [49]. Mexican learners obtained higher overall than their Spanish friends, a result of the researcher's credit to the effects of current tough financial situations in Spain and the overly huge expectations of the nation's youth [49]. Miguez, Gil [50] predict difficult economic times in Spain after the commencement of the global monetary crisis in 2008. They inform that miserable job possibilities in Spain will make it incredibly hard for its people to deal with the long-term impacts of the global slowdown. In fact, it appears that both people hold reasons to endeavor for resolution. However, it is essential for teachers to be knowledgeable that macroeconomic health can change evaluation outcomes and student educational needs.

While teachers cannot regulate alterations in the outside atmosphere, they can encourage entrepreneurship learning that guides to enhanced management self-efficacy among learners [39]. Enhancing self-efficacy can be crucial for coming leaders who require understanding they can alter the status quo. The contemporary financial crisis in Spain could depart the nation towards a more entrepreneurial and fair community, or it could create it to return to a common, male-centered business setting [51]. To block the nation from going back, teachers can improve equip the next generation of experts to undertake the difficulties that invite social and support improvement in the manner [52]. In addition, researchers have recorded that leadership and economic growth are interrelated [53, 54]. Accordingly, universities must perform an effective role in promoting leaders who can perform as agents of change to develop economic and democratic conditions [55]. Promoting entrepreneurship on its own may not be sufficient to address the obstacles that Mexico and Spain meet. An aggregate of entrepreneurship and leadership improvement may be a more thoughtful strategy. The aforementioned shows the necessity to assign greater importance to the development of leadership efficacy, which may be an effective procedure for improving the overall situation of the community [55-57].

Like entrepreneurship, the notion of leadership, and therefore leadership agendas, is susceptible to cultural discrepancies [58]. This presents questions about the role of capability members from various territories of the world in pinpointing the right leadership standard for their learners, given their cultural experience. Managing these questions can assist teachers to arrange their assignments more efficiently and support enable a successful community by generating the successive generation of leaders who are able to alter the hostile elements associated with their homeland [59]. Teachers can discover the answer in the job of Posner [48] which operates the Five Practices Exemplary leadership model to estimate learner leadership in several territories of the world. Learners who model the path, inspire a shared sight, challenge methods, enable others to act, and drive hearts at target levels may be well on their way to becoming transformational leaders who can lift others and themselves to higher levels of performance [48].

\section{In the perspective of entrepreneurial leadership and culture}

Javidan, Dorfman [60] examined 61 societies in terms of culture and leadership dimensions. The six dimensions of leadership in their study were charismatic/values-based, teamoriented, participatory, human-oriented, autonomous, and selfprotective. The writers of the research, called the GLOBE plan, decided that culture can affect thoughts of effective leadership. The aforementioned case was examined by Graen [61] who analyzed the GLOBE study for disregarding the leadership dimensions connected with transformational leadership theory and leader-member exchange. The idea is that the GLOBE design based its judgments on biased and culturally inconsiderate assumptions, and asked the study writers to promote the further study to address this issue.

Furthermore, Munley [62] records that cross-cultural leadership investigations run the risk of fostering generalizations about whole communities based on particular personal replies, probably providing a direction to cultural stereotypes. In this regard, , Hidalgo, Manzur [63] claim that more study on cultural gaps among Latin American countries is required to narrow the knowledge gap originally addressed by the researchers in the Globe project.

Exemplary in the view of entrepreneurial leadership and culture is defined by six characteristics, i.e (1) charismatic/value-based, (2) team-oriented, (3) participatory, (4) human-oriented, (5) self-governing, and (6) self-protective. Nevertheless, the highly particular features of qualitative study can lead to misleading judgments in creating conclusions due to its own particular features.

\section{Entrepreneurial leadership, employment, and gender}

Junior experts with little job experience are more possible to hold their job or obtain another job when they determine to create a switch if they have a bachelor's degree [64]. Likewise, learners who are already able to earn money are more engaged in moving school. Government systems are required so that learners can favorably finish their education. In addition to getting access to block learners from moving school early, entrepreneurship teachers can assist them to acquire the abilities they require to succeed in the workplace and adapt to start a business if they wish to do so [65].

Yet, in the study, entrepreneurship and self-employment are two names that people apply conversely and have become a common solution to the problem of unemployment and underperforming economies. Cueto, Mayor [66] managed research in Spain to investigate the urge behind entrepreneurship. They discovered that self-employment raised or declined based on the overall unemployment relationship. Including high unemployment, individuals are more probable to engage in entrepreneurial enterprises that lead to selfemployment. The conventional approach to explaining entrepreneurship suggests an alternative to obtaining a job. Under this view, entrepreneurship happens more out of a requirement to find work than of an expert purpose [66]. 
Results from research designed to include transformational leadership, emotional intelligence, and gender identity among 431 undergraduate students in Spain showed that emotional intelligence and gender were connected with transformational leadership [67]. This strengthens the claim that performing educational plans to grow transformational leadership, together with entrepreneurship training, can assist promote gender equity and enable fresh professionals to better adapt to today's social and economic conditions. Relating to this analysis, we can decide that characteristics such as transformational leadership practices, emotional intelligence, facilitate the growth of exemplary which has an influence on the promotion of gender equity that triggers efficacy and makes the entrepreneurial attitude to start entrepreneurship.

\section{In the perspective of a leader as an entrepreneur}

The exemplary entrepreneur fuses the character of a traditional manager who is counting and objective with the qualities of a gentle leader [68]. This is in accordance with the suggestions put forward by Nirmala and Kumar [69] whose investigation suggests that universities promote the growth of quantitative thought, critical thinking, and self-motivation. Shivoro, Shalyefu [70] combine leadership competencies to this list. Accordingly, entrepreneurship is not a synonym for self-employment or an option to obtain a job. Entrepreneurial development comprises a set of abilities that support individuals succeed in a broader context, including corporate life, social roles, and business making [71].

Exemplary diction is also accompanied by calculating, objective, gentle diction, quantitative reasoning, critical thinking, self-motivation, and transformational style. Therefore, educators need to adopt these dictions to be applied in the entrepreneurship education process.

\section{In the Perspective of Authentic Leadership}

Kernis and Goldman [72] conclude that authenticity has five fundamental themes: (a) self-understanding and the capacity to allow vagueness, notice events correctly, and not suspiciously misrepresent undesired aspects of the self; (b) living completely in the moment, which means being adaptive, flexible, and accepting that one is a dynamic thing; (c) trust in inner experiences to control behavior; (d) independence and, indifferent of happenings, one has the confidence that opportunity exists; and (e) a productive strategy to life driven by a firm trust in oneself, a readiness to adjust, and a denial to regress to restricting habits or principles models. Developing proof in the business and management literature suggests that authentic leadership strategies aid obtain positive organizational results, which combine improved members and organizational self-esteem, kindness, and performance [73].

Authentic leadership highlights the ethical outlook of the individual leader led by self-knowledge [74-76]. Ilies, Morgeson [77] establish authentic leaders as those who are extremely conscious of their values and beliefs, they are selftrusting, trustworthy, dependable, and reliable, and they center on raising members' power, growing their reasoning, and generating a positive situation, and interesting, organizational context. Authentic leaders demonstrate intentionality, strength, encouragement, and resilience to developing action [75].

\section{In the perspective of Authenticity and Self}

Authentic leadership is popularly connected with being "true to yourself" and operating according to one's own beliefs. Therefore, authentic leadership does not significantly assume one's belief is good or echoes the needs of others. On the other hand, at the least and most individual level, authentic leaders have a well-developed self-thought, are clear about their values and assumptions, have expanded intentions, and work in behaviors that are compatible with their self-concept [78].

Challenging school settings, school district politics, and neoliberal educational policies that foster distrust between educators and leaders complicate authenticity build a cynical status quo, and create ethical difficulties that can influence individual and social constructs of authenticity [79, 80]. Badaracco and Ellsworth [81] Badaracco and Ellsworth (1989) explain that authentic leaders find harmony by adjusting their values and prejudices to guide decision-making. However, attempting for authenticity and consistency can be an effort because the self can also be formed, too often to the damage, by organizational structures, processes, and by some ritual trappings that limit creativity and drive ( [82].

\section{In the perspective of Theorizing Authentic and Socially Just leadership}

Both authentic and social justice leaders understand and embrace complex school-community contexts and answer by attracting on moral purposes to create connections and nurture positive cultures that inspire mutual obligation and action [14, 83, 84]. Anderson [85] uggests a layered method to leadership authenticity that highlights: (a) individual authenticity; (b) organizational authenticity, and (c) community authenticity. Educational inequalities can remain unchallenged when leaders have personal authenticity, but fail to acknowledge profoundly the organizational and societal issues that shape schools, faculty, families, and students.

Social justice leadership improves authentic leadership by highlighting important considerations and prioritizing democratic and comprehensive leadership efforts [86, 87]. From a social justice viewpoint, authenticity is not just about doing according to an inactive set of individual and professional values or balancing individual, organizational, and societal authenticity, but recognizing, knowing, and addressing injustices connected with racism, poverty, and segregation that are both persistent and thrive in schools and communities. Theoharis [83] outlines social justice leadership in terms of how school principals address matters of race, class, gender, disability, sexual orientation, and other conditions that have historically and currently marginalized. Theoharis [88] erm social justice leaders as people who examine and present solutions to issues that create and recreate social injustice. These leaders raise problems and are not corrupted by business models so they find time to read broadly, and have a well-developed social analysis, but do not 
follow the party line. They build learning in their schools [85, 89]. Exemplary figures struggles can be grouped into 1) framing injustice as possible, 2) a morally driven leader who effectively communicates her enthusiasm, passion, and social justice orientation to everyone [90].

\section{CONCLUSION}

The author concludes that the quantitative research design is more of a confirmatory analysis that seeks to solve problems through latent variables that are poured into indicators as outlined in the instrument to show the strength of Kousez and Posner's exemplary leadership and in mixed methods design studies focusing on the Five Kennedy Leadership Qualities. Kennedy five leadership qualifies of cultural differences a) making diversity a priority, b) getting to know people and their differences, c) enabling rich communication, d) accountability as a core value, e) mutualism as the ultimate arbiter. Meanwhile, in the qualitative design, exemplary diction is more heroic, which relies on one role model with all the sacrifices, dedication, risk, and skills to adapt the application of various leadership styles associated with exemplary diction. It is clear to us that to apply exemplary diction requires sharp intuition of leadership, the intelligence to mix several styles, and the courage to take risks.

\section{References}

[1] Hurwitz, M. and S. Hurwitz, Leadership is half the story. 2018: University of Toronto Press.

[2] Stehlik, D., Failure: The impartial executioner of leaders, followers, and their organizations. Journal of Practical Consulting, 2014. 5(1): p. 41-52.

[3] Tolstikov-Mast, Y., Global followership: The launch of the scholarly journey, in Advances in global leadership. 2016, Emerald Group Publishing Limited.

[4] Chaleff, I., The courageous follower: Standing up to \& for our leaders. 2009: Berrett-Koehler Publishers.

[5] Martin, R., A review of the literature of the followership since 2008: The importance of relationships and emotional intelligence. Sage Open, 2015. 5(4): p. 2158244015608421.

[6] Uhl-Bien, M., et al., Followership theory: A review and research agenda. The leadership quarterly, 2014. 25(1): p. 83-104.

[7] Collinson, D., Rethinking followership: A poststructuralist analysis of follower identities. The leadership quarterly, 2006. 17(2): p. 179-189.

[8] Schwab, K.W., Teaching and Learning Courageous Followership: An Action Research Study. 2017, University of the Incarnate Word.

[9] McDonald, C.J., An Exemplary Leader?: New Zealand and Decolonization of the Cook Islands and Niue. The Journal of Pacific History, 2020. 55(3): p. 394-417.

[10] Khan, A.A. and K.A. Soomro, Exemplary Organizational Leadership-An Exploratory Study in light of Prophet Muhammad's (Peace Be Upon Him) Leadership Traits.
Sindh Economics \& Business Review International, 2020. 2(1): p. 75-87.

[11] Acintya Pramudhita, C. and A. Ghazali, An Assessment of Exemplary Leadership at PT Industri Telekomunikasi Indonesia (INTI). 2017.

[12] Khan, H., Commitment to Supreme Performance: An Empirical Study Predicting Exemplary Leadership with Appropriate Leadership: Transactional (ALT-) Style. Academy of Business Research Journal, 2020. 3: p. 7-43.

[13] Ghias, W., S. Hassan, and M.T. Masood, Does Courageous Followership contribute to Exemplary Leadership Practices: Evidence from Pakistan? NUML International Journal of Business \& Management, 2018. 13(1): p. 11-21.

[14] Dematthews, D.E. and E. Izquierdo, Authentic and social Justice leadership: A case study of an exemplary principal along the US-Mexico border. Journal of School Leadership, 2017. 27(3): p. 333-360.

[15] Eisenschmidt, E., et al., Virtues that create purpose for ethical leadership: Exemplary principals from Estonia and Finland. Journal of Beliefs \& Values, 2019. 40(4): p. 433-446.

[16]Zaharris, M., et al., The Impact of Spirituality on School Leadership. Education Leadership Review, 2017. 18(1): p. 81-95.

[17] Díaz, E.R., C.G. Sánchez-Vélez, and L. Santana-Serrano, Integrating the Five Practices of the Exemplary Leadership Model into Entrepreneurship Education. International Journal for the Scholarship of Teaching and Learning, 2019. 13(3): p. 10.

[18] Peter, B. and O.A. Sunday, Exemplary Leadership and Employee Commitment in Private Health Sector in Port Harcourt, Rivers State; Nigeria. 2018.

[19] Maiden, G., Using reflection and visual representation to analyse and build leadership capacity, through a personal account of exemplary leadership. International Practice Development Journal, 2017. 7(2).

[20] Martín Pérez, M., Leadership Strategies That Exemplary K-12 Latina Superintendents in California Use to Create an Organizational Culture of Inclusiveness Using Kennedy's Five Leadership Qualities of Cultural Differences. 2021.

[21]Jackson, E., Meaning-centered leadership: How exemplary technology leaders create organizational meaning. 2017, Brandman University.

[22] Hodge, S.K., Meaning makers: A mixed-methods case study of exemplary chief executive officers of engineering technology organizations and the behaviors they use to create personal and organizational meaning. 2017, Brandman University.

[23]Dodge, L., The Culturally Intelligent School Leader: Leadership Strategies of Exemplary Elementary School Principals in Creating a Culture of Inclusiveness. 2021.

[24]Browing, F., From counselor to CEO: Opportunities, challenges, and rewards. Retrieved August, 2007. 15: p. 2008. 
[25] Cowie, M. and M. Crawford, Principal preparation-still an act of faith? School leadership and management, 2007. 27(2): p. 129-146.

[26] Brauckmann, S. and P. Pashiardis, A validation study of the leadership styles of a holistic leadership theoretical framework. International Journal of Educational Management, 2011.

[27] Duignan, P., Educational leadership: Key challenges and ethical tensions. 2007: Cambridge University Press.

[28] Kouzes, J.M. and B.Z. Posner, LPI®: Leadership Practices Inventory ${ }^{\circledR} .2013$.

[29] Kouzes, J.M. and B.Z. Posner, The Jossey-Bass academic administrator's guide to exemplary leadership. Vol. 131. 2003: John Wiley \& Sons.

[30] Kouzes, J.M. and B.Z. Posner, The Leadership Challenge, 3rd Edn San Francisco. 2002, CA: Jossey-Bass.[Google Scholar].

[31] Bass, B.M. and B.J. Avolio, Transformational leadership and organizational culture. The International Journal of Public Administration, 1994. 17(3-4): p. 541-554.

[32]Mulford, B. and H. Silins, Revised models and conceptualisation of successful school principalship for improved student outcomes. International Journal of Educational Management, 2011.

[33] Orr, M.T. and S. Orphanos, How graduate-level preparation influences the effectiveness of school leaders: A comparison of the outcomes of exemplary and conventional leadership preparation programs for principals. Educational Administration Quarterly, 2011. 47(1): p. 18-70.

[34]Leithwood, K., D. Tomlinson, and M. Genge, Transformational school leadership, in International handbook of educational leadership and administration. 1996, Springer. p. 785-840.

[35] Sammons, P., et al., Exploring the impact of school leadership on pupil outcomes: Results from a study of academically improved and effective schools in England. International journal of educational management, 2011.

[36] Leithwood, K., Leadership for school restructuring. Educational administration quarterly, 1994. 30(4): p. 498518.

[37]Díaz, E.R., C.G. Sánchez-Vélez, and L. Santana-Serrano, International Journal for the Scholarship of Teaching and Learning. 2019.

[38] Villasana, M., R. Alcaraz-Rodriguez, and M.M. Alvarez, Examining entrepreneurial attributes of Latin American female university students. Gender and Education, 2016. 28(1): p. 148-166.

[39] Bagheri, A., Z.A. Lope Pihie, and S.E. Krauss, Entrepreneurial leadership competencies among Malaysian university student entrepreneurial leaders. Asia Pacific Journal of Education, 2013. 33(4): p. 493508.

[40] Costa, M.J.P., Cultura postmaterialista y variaciones en el espíritu emprendedor. Investigaciones Europeas de Dirección y Economía de la Empresa, 2011. 17(1): p. 3755.
[41] Galloway, L., I. Kapasi, and K. Sang, Entrepreneurship, leadership, and the value of feminist approaches to understanding them. Journal of Small Business Management, 2015. 53(3): p. 683-692.

[42] Anderson, B.S. and J.G. Covin, Entrepreneurial orientation: disposition and behavior, in Handbook of Research On Entrepreneurship. 2014, Edward Elgar Publishing.

[43] Shafique, I., M. N Kalyar, and B. Ahmad, The nexus of ethical leadership, job performance, and turnover intention: The mediating role of job satisfaction. Interdisciplinary Description of Complex Systems: INDECS, 2018. 16(1): p. 71-87.

[44]Briales, Á., Emprendeudores fracasados: individualización neoliberal en los discursos sobre el desempleo. Recerca. Revista de pensament i anàlisi, 2017: p. 79-104.

[45] Cabrera, A.F., W. De Vries, and S. Anderson, Job satisfaction among Mexican alumni: A case of incongruence between hunch-based policies and labor market demands. Higher Education, 2008. 56(6): p. 699722.

[46] Muchiri, M. and A. McMurray, Entrepreneurial orientation within small firms: A critical review of why leadership and contextual factors matter. Small Enterprise Research, 2015. 22(1): p. 17-31.

[47]Lewis, L.J., J. Rayfield, and L.L. Moore, Supervised Agricultural Experience: An Examination of Student Knowledge and Participation. Journal of Agricultural Education, 2012. 53(4).

[48] Posner, M., Attentional networks and consciousness. Frontiers in psychology, 2012. 3: p. 64.

[49] Carballeira, M., J.-Á. González, and R.J. Marrero, Diferencias transculturales en bienestar subjetivo: México y España. Anales de Psicología/Annals of Psychology, 2015. 31(1): p. 199-206.

[50] Miguez, G.C., M.D.G. Gil, and M.V. Lafuente, EFFECTS OF THE GREAT RECESSION ON THE SPANISH ECONOMY. Current Politics \& Economics of Europe, 2010. 21(4).

[51]Bark, A.S.H., J. Escartín, and R. van Dick, Gender and leadership in Spain: A systematic review of some key aspects. Sex Roles, 2014. 70(11-12): p. 522-537.

[52] Jabbarov, U.A., Significance of Foreign Pedagogical Experience in Preparing English Language Teachers. Eastern European Scientific Journal, 2018(2).

[53] Clark, K.E. and M.B. Clark. Measures of leadership. in Conference on Psychological Measures and Leadership, Oct, 1988, San Antonio, TX, US. 1990. Leadership Library of America.

[54] Williams, R.T., The on-going farm crisis: Extension leadership in rural communities. Journal of Extension, 1996. 34(1).

[55]Cantón, A., Educating Transformational Leaders in Mexico at Universidad De Monterrey. New Directions for Higher Education, 2016. 175: p. 57-64.

[56] Mizrathiturkatli, N. and S. Guney, Ideal leadership perception of undergraduate and graduate students: An 
application. Business Management Dynamics, 2016. 6(6): p. 17.

[57] Ives, A., Entrepreneurship education as a new model for leadership education. Journal of leadership studies, 2011. 5(2): p. 85-88.

[58] Pittaway, L., O. Rivera, and A. Murphy, Social identity and leadership in the basque region: a study of leadership development programmes. Journal of Leadership \& Organizational Studies, 2005. 11(3): p. 1729.

[59] Pruett, M., Entrepreneurship education: Workshops and entrepreneurial intentions. Journal of Education for Business, 2012. 87(2): p. 94-101.

[60] Javidan, M., et al., In the eye of the beholder: Cross cultural lessons in leadership from project GLOBE. Academy of management perspectives, 2006. 20(1): p. 67-90.

[61] Graen, G.B., In the eye of the beholder: Cross-cultural lesson in leadership from project GLOBE: A response viewed from the third culture bonding (TCB) model of cross-cultural leadership. Academy of Management Perspectives, 2006. 20(4): p. 95-101.

[62] Munley, A.E., Culture differences in leadership. IUP Journal of Soft Skills, 2011. 5(1).

[63] Hidalgo, C.P., et al., Quantifying cultural distances between countries: a Latin American analysis. Cuadernos de Administración, 2007. 20(33): p. 253-272.

[64] Acosta-Ballesteros, J., M.d.P. Osorno-del Rosal, and O.M. Rodríguez-Rodríguez, Underemployment and employment among young workers and the business cycle in Spain: the importance of education level and specialisation. Journal of Education and Work, 2018. 31(1): p. 28-46.

[65] Albornoz, P.C., Is business creation the mean or the end of entrepreneurship education?: a multiple case study exploring teaching goals in entrepreneurship education. Journal of technology management \& innovation, 2013. 8(1): p. 1-10.

[66]Cueto, B., M. Mayor, and P. Suárez, Entrepreneurship and unemployment in Spain: a regional analysis. Applied Economics Letters, 2015. 22(15): p. 1230-1235.

[67]Lopez-Zafra, E., R. Garcia-Retamero, and M.P.B. Martos, The relationship between transformational leadership and emotional intelligence from a gendered approach. The Psychological Record, 2012. 62(1): p. 97-114.

[68] Minica, M., Approach of The Manager-LeaderEntrepreneur Relation from The Viewpoint of Applied Microeconomics. Analele Universitatii'Eftimie Murgu'Resita. Fascicola II. Studii Economice, 2017.

[69] Nirmala, K. and S.S. Kumar, The impact of basic, higherorder thinking and affective skills on graduate employability. IUP Journal of Soft Skills, 2018. 12(1): p. 7-28.

[70] Shivoro, R., R. Shalyefu, and N. Kadhila, Perspectives on graduate employability attributes for management sciences graduates. South African Journal of Higher Education, 2018. 32(1): p. 216-232.
[71] Pache, A.-C. and I. Chowdhury, Social entrepreneurs as institutionally embedded entrepreneurs: Toward a new model of social entrepreneurship education. Academy of Management Learning \& Education, 2012. 11(3): p. 494510.

[72] Kernis, M.H. and B.M. Goldman, Assessing stability of self-esteem and contingent self-esteem. Self-esteem issues and answers: A sourcebook of current perspectives, 2006: p. 77-85.

[73] Grandey, A.A., et al., Is "service with a smile" enough? Authenticity of positive displays during service encounters. Organizational Behavior and Human Decision Processes, 2005. 96(1): p. 38-55.

[74] Gardner, W.L., et al., Authentic leadership: A review of the literature and research agenda. The leadership quarterly, 2011. 22(6): p. 1120-1145.

[75] Avolio, B.J., et al., Unlocking the mask: A look at the process by which authentic leaders impact follower attitudes and behaviors. The leadership quarterly, 2004. 15(6): p. 801-823.

[76] Walumbwa, F.O., et al., Authentic leadership: Development and validation of a theory-based measure. Journal of management, 2008. 34(1): p. 89-126.

[77] Ilies, R., F.P. Morgeson, and J.D. Nahrgang, Authentic leadership and eudaemonic well-being: Understanding leader-follower outcomes. The leadership quarterly, 2005. 16(3): p. 373-394.

[78] Shamir, B. and G. Eilam, "What's your story?" A lifestories approach to authentic leadership development. The leadership quarterly, 2005. 16(3): p. 395-417.

[79] Cranston, N., L.C. Ehrich, and M. Kimber, Ethical dilemmas: The "bread and butter" of educational leaders' lives. Journal of Educational Administration, 2006.

[80] Shapiro, J.P. and R.E. Hassinger, Using case studies of ethical dilemmas for the development of moral literacy: Towards educating for social justice. Journal of Educational Administration, 2007.

[81] Badaracco, J. and R.R. Ellsworth, Leadership and the Quest for Integrity. 1989: Harvard Business Press.

[82] Duignan, P.A. and N. Bhindi, Authenticity in leadership: An emerging perspective. Journal of educational administration, 1997.

[83] Theoharis, G., Social justice educational leaders and resistance: Toward a theory of social justice leadership. Educational administration quarterly, 2007. 43(2): p. 221258.

[84] Wilson, M., Critical reflection on authentic leadership and school leader development from a virtue ethical perspective. Educational Review, 2014. 66(4): p. 482496.

[85] Anderson, G.L., Advocacy leadership: Toward a postreform agenda in education. 2009: Routledge.

[86] DeMatthews, D. and H. Mawhinney, Social justice leadership and inclusion: Exploring challenges in an urban district struggling to address inequities. Educational administration quarterly, 2014. 50(5): p. 844881. 
[87]DeMatthews, D., Effective leadership is not enough: Critical approaches to closing the racial discipline gap. The Clearing House: A Journal of Educational Strategies, Issues and Ideas, 2016. 89(1): p. 7-13.

[88] Theoharis, G., Disrupting injustice: Principals narrate the strategies they use to improve their schools and advance social justice. Teachers College Record, 2010. 112(1): p. 331-373.

[89] Place, A.W., et al., Principals' perspectives of social justice in public schools. International Journal of Educational Management, 2010.

[90]Furman, G., Social justice leadership as praxis: Developing capacities through preparation programs. Educational administration quarterly, 2012. 48(2): p. 191229. "An approach to graphs of linear forms (Unpublished work style)," unpublished.

Sulpakar was born in Bandar Dalam on February 05, 1969. In 1995 he obteined s1 degree in Saburai University, faculty of Social Science and Political Science. In 2006 he obtained a magister degree in master in management from Bandar Lampung University.

$\mathrm{He}$ is actively working at Provincial Educational Affairs of Lampung Province as a head.

\section{Contribution of individual authors to the creation of a scientific article (ghostwriting policy)}

Ridwan carried out the analysis the articles

Herdian has searched and collected articles.

Sudjarwo and Hasan Hariri were responsible for the content analysis.

\section{Sources of funding for research presented in a scientific article or scientific article itself}

No any parties funded this articles for publications

Creative Commons Attribution License 4.0 (Attribution 4.0 International, CC BY 4.0)

This article is published under the terms of the Creative Commons Attribution License 4.0

https://creativecommons.org/licenses/by/4.0/deed.en US 